\title{
318. 撮影条件決定用簡易蛍光光度計の製作
}

Development of the simple fluorescent photometer for the decision of exposure condition

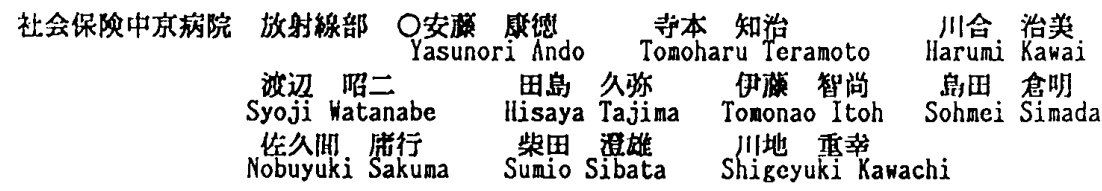

【目的】特利离度な技術を使用せずに、万能基板に手配稳による

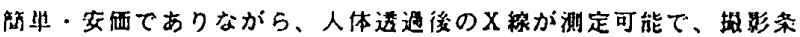
件決定の一政となる简易篮光光度計を整作する。

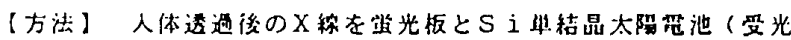

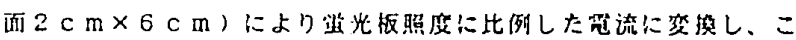

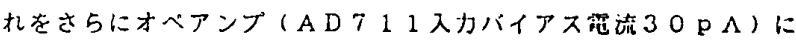

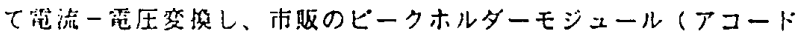
需子KK のビーク值、すなわ方篮光板照度のビーク值を测定する装设とする。

図1に本䒾四のプロック図を、図2にその主要な部分の回路図を 示吉。

【钴果】军真1に回路图中のA点における來茫裂インバーター㸚 周 $\mathrm{KXO}-50 \mathrm{~F}$ :よる盖光强度波形を示す。

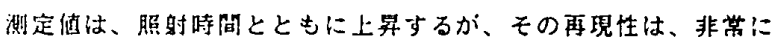
高く、炤射時阔を一定としたときは、たいへん良い精度でヒーク值 を测定出来た。

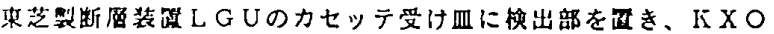
$-50 \mathrm{~F}$ に $70 \mathrm{kV} \quad 160 \mathrm{~mA} \quad 0.02$ 秒と $80 \mathrm{kV} 320$ $\mathrm{m} \mathrm{A} \quad 0.02$ 秒でのアクリル厚と测定值の関係をグラフと表にて 下段に示与。

これより、各棸作にてアクリル原 $5 \mathrm{~m} \mathrm{~m}$ の薪を分解可能でった。

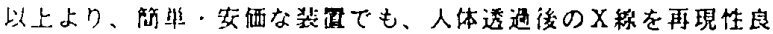
く测定可能でありテスト照射より胡堁棸件を決定するには、十分な 性能であった。

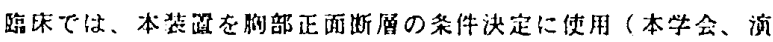

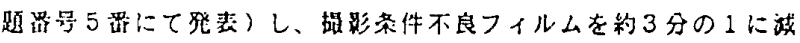

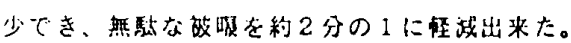
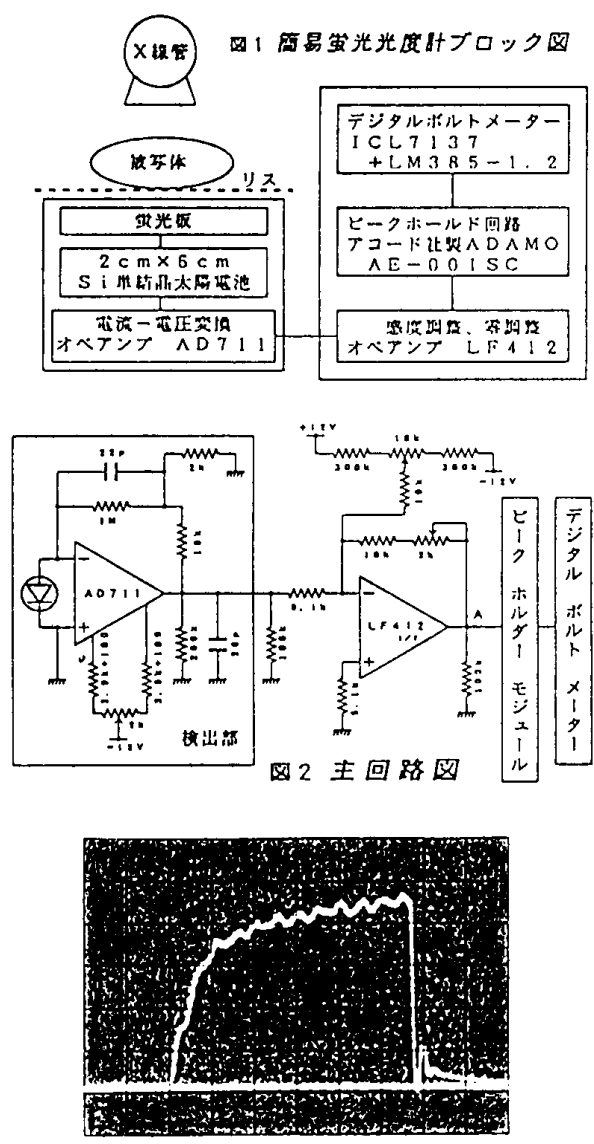

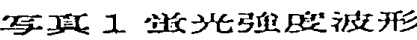
$70 \mathrm{kV} 160 \mathrm{mAO}$. O3SEC
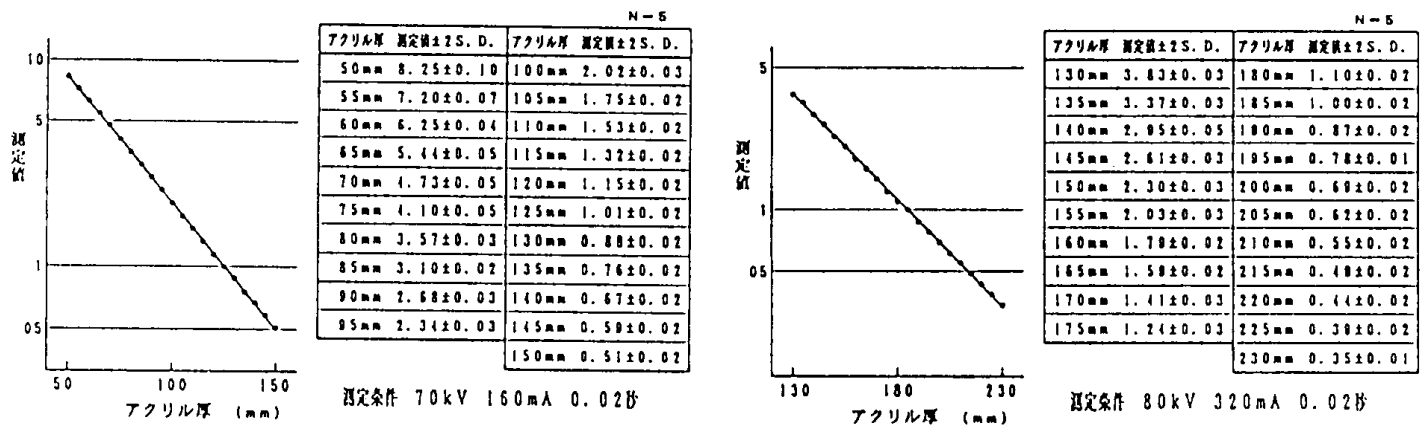